\title{
Further contribution to the low latitude leaf assemblage from the late Oligocene sediments of Assam and its phytogeographical significance
}

\author{
Gaurav Srivastava* and R C Mehrotra \\ Birbal Sahni Institute of Palaeobotany, 53 University Road, Lucknow 226 007, India. \\ ${ }^{*}$ Corresponding author. e-mail: gaurav_jan10@yahoo.co.in
}

An assemblage of fossil leaves is described from the late Oligocene (Chattian 28.1-23 Ma) sediments of Assam, which was located in a low palaeolatitude $\left(\sim 10-15^{\circ} \mathrm{N}\right)$ during the period of sedimentation. It includes four new fossil leaves resembling Firmiana and Pterygota of the Malvaceae s.l. and Paranephelium and Sapindus of the Sapindaceae. The present study suggests that the floral migration between India and southeast Asia had occurred after the late Oligocene. Our study is in congruence with the earlier published data suggesting a floral migration had occurred after the complete suturing of two landmasses by the Neogene.

\section{Introduction}

Globally, the late Oligocene (Chattian 28.1-23 Ma) was the time of last significant global warmth period on our blue planet Earth (Zachos et al. 2001). In India, the only well known exposure of the late Oligocene sedimentary basin is in northeastern part, where substantial tectonic activity has been going on since the onset of the Indian and Eurasian plate collision at $\sim 56 \mathrm{Ma}$ (Qinghai et al. 2012).

The Makum Coalfield is a well known basin having exposure of the late Oligocene sediments. The coalfield is important because (i) it is one of the largest coal producing basins in northeast India and (ii) it contains a well diversified low latitude palaeoflora (Awasthi et al. 1992; Awasthi and Mehrotra 1995; Mehrotra et al. 2009; Srivastava and Mehrotra 2010a, 2012, 2013a, b; Srivastava et al. 2012a). Infact, there is no other Oligocene sedimentary basin in the Indian subcontinent which contains such a rich and diversified assemblage of plants. The basin was situated at a low palaeolatitude, i.e., $\sim 10^{\circ}-15^{\circ} \mathrm{N}$ (Molnar and Stock 2010) and the sediments were deposited in a deltaic, mangrove or lagoonal environment (Awasthi and Mehrotra 1995; Mehrotra et al. 2003; Srivastava et al. 2012b). The coalfield consists of Baragolai, Ledo, Namdang, Tikak, Tipong and Tirap collieries, lies in between the latitudes $27^{\circ} 15^{\prime}-27^{\circ} 25^{\prime} \mathrm{N}$ and longitudes $95^{\circ} 40^{\prime}-95^{\circ} 55^{\prime} \mathrm{E}$ (figures 1 and 2 ) and is located along the outermost flank of the Patkai range. On the southern and southeastern sides are the hills, which rise abruptly to heights of 300-500 $\mathrm{m}$ from the alluvial plains of the Buri Dihing and Tirap rivers respectively.

The fossils collected for the present study belong to the Tikak Parbat Formation being considered to be late Oligocene (Chattian 28.1-23 Ma) in age on the basis of regional lithostratigraphy (Pascoe 1964), remote sensing (Ganju et al. 1986) and

Keywords. Makum coalfield; Malvaceae; Palaeogene; Sapindaceae; Tikak Parbat Formation; Barail. 


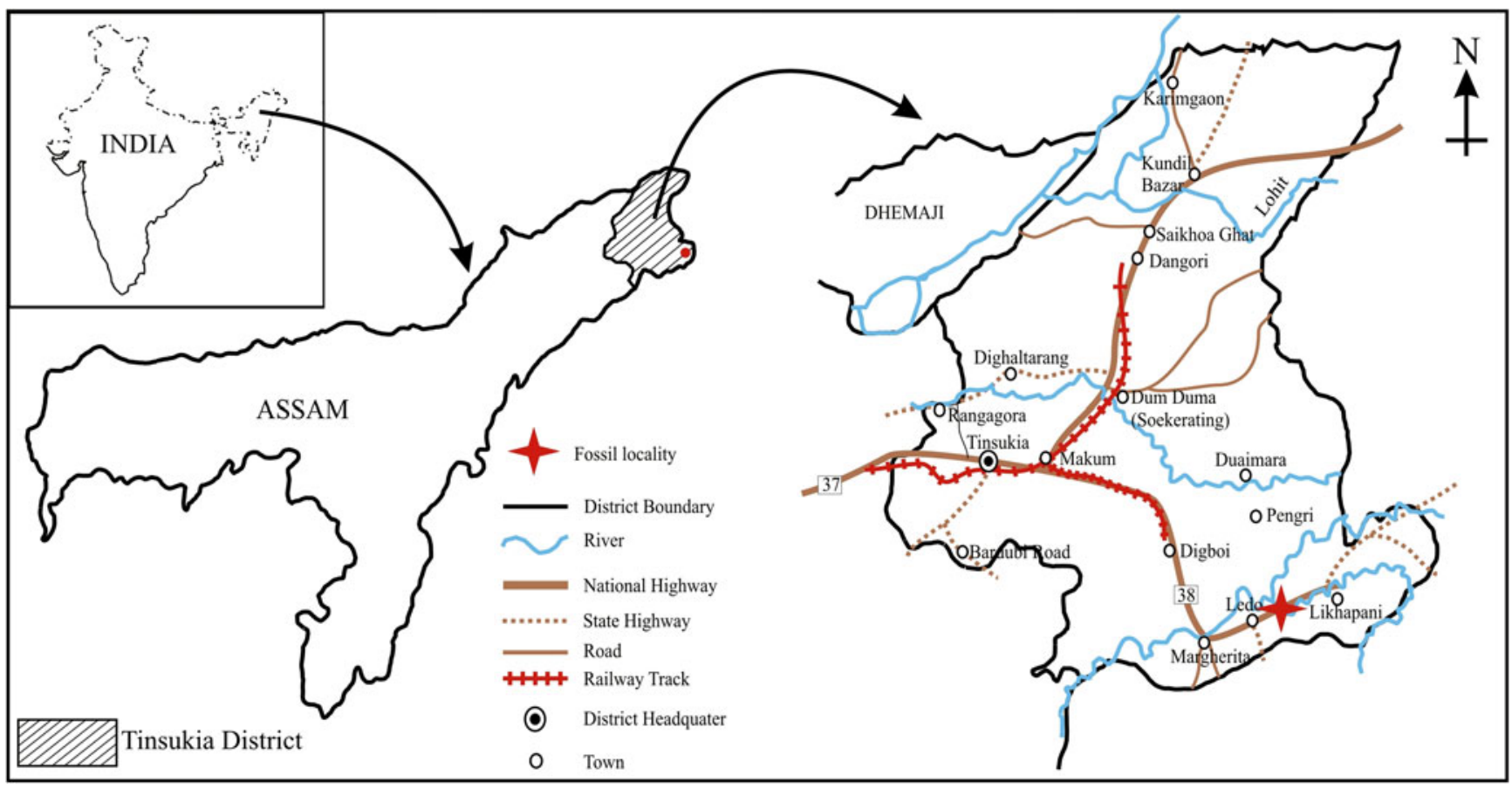

Figure 1. Map of Assam showing the fossil locality in the Tinsukia District.

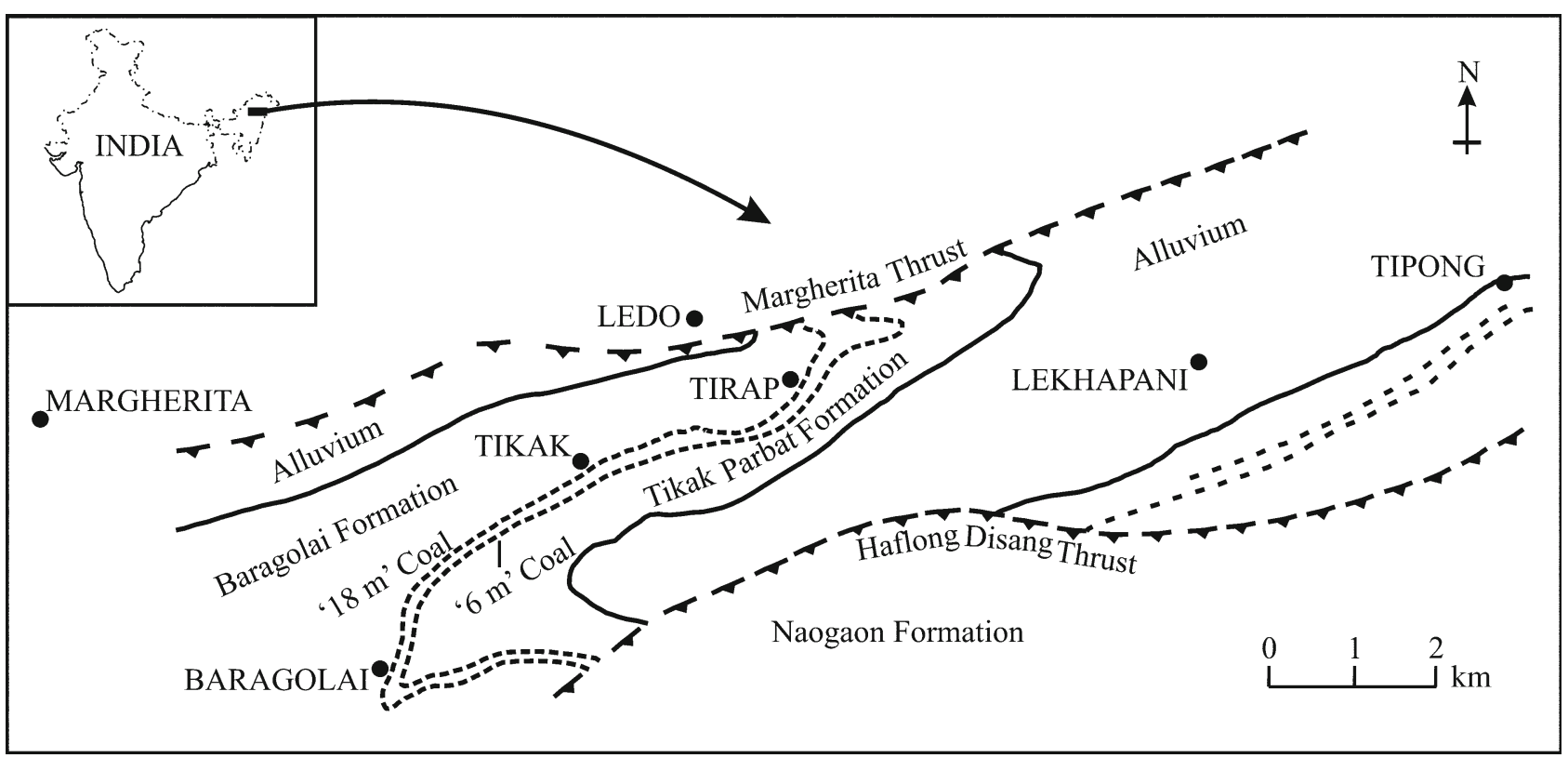

Figure 2. Simplified geological map of Makum Coalfield, Assam (after Ahmed 1996).

biostratigraphic controls (Kumar et al. 2012). The formation has five coal seams confined within the basal $200 \mathrm{~m}$ section (Misra 1992).

The Tikak Parbat Formation constitutes alternations of sandstone, siltstone, mudstone, shale, carbonaceous shale, clay and coal seams (Misra 1992). However, the plant remains are mainly confined to the grey carbonaceous and sandy shales.
The formation is underlain by $300 \mathrm{~m}$ of predominantly massive, micaceous or ferruginous sandstones that incorporate the Baragolai Formation, which is successively underlain by $1100-1700 \mathrm{~m}$ of thin-bedded fine-grained quartzitic sandstones with thin shale and sandy shale partings that constitute the Naogaon Formation (Mishra and Ghosh 1996). The three formations together represent the 
Barail Group (figure 2). In Barail Group, there is an upward trend of marine to non-marine palaeoenvironments, which symbolizes the infilling of a linear basin on the eastern edge of the Indian plate. The detailed sedimentary information of the Tirap mine section has been given by Kumar et al. (2012).

\section{Material and methods}

Material for the present study was collected from the Tirap colliery of the Makum Coalfield, Tinsukia District, Assam (figures 1, 2). The specimens were first cleared with the help of a fine chisel and hammer and then photographed in natural low angled light using 10 megapixel digital camera (Canon SX 110). The terminology used in describing the fossil leaf is based on Hickey (1973), Dilcher (1974) and Ellis et al. (2009). The type specimens are housed in the museum of the Birbal Sahni Institute of Palaeobotany, Lucknow.

\section{Systematic description}

Order: Malvales Juss.

Family: Malvaceae Juss. s.l.

Genus: Firmiana Marsili

Species: F. oligocenica Srivastava and Mehrotra, sp. nov. (figures 3a, 4a, c)

Description: Leaf simple, palmately lobed, three lobes seen; preserved lamina length of single lobe $6.5 \mathrm{~cm}$, maximum width of single lobe $3.6 \mathrm{~cm}$ (near the middle); apex attenuate; base cordate; margin entire; texture chartaceous; attachment with petiole normal, preserved length and width $1.7 \times$ $0.24 \mathrm{~cm}$; venation pinnate, actinodromous; primary veins stout in thickness, 5 in number, nearly straight; secondary veins 8 pairs visible, $0.4-0.7 \mathrm{~cm}$ apart, predominantly alternate, angle of divergence moderate-wide acute $\left(57^{\circ}-74^{\circ}\right)$, more or less uniform, moderately thick, smoothly curved; intersecondary veins not seen; tertiary veins percurrent and recurved, angle of origin RR; other features not visible.

Affinities: The characteristic features of the fossil leaf, viz., palmately lobed lamina, attenuate apex, cordate base, entire margin, actinodromous venation and percurrent tertiary veins suggest its close affinity with that of Firmiana-Sterculia of the family Malvaceae s.l. (formerly Sterculiaceae). A large number of herbarium sheets of Firmiana colorata Roxb. (=Sterculia colorata Roxb.), Pterygota alata Thwaites (syn. Sterculia alata Roxb.),
Sterculia acerifolia Hemsl., S. bidwilli Hk. ex Benth., S. coccinea Roxb., S. diversifolia G. Don, S. foetida Linn., S. guttata Roxb., S. pallens Wall. ex Hochr., S. platanifolia L. f., S. rupestris Benth., $S$. trichosiphon Benth., S. versicolor Wall. and $S$. urens Roxb. of the same family were examined in the Central National Herbarium, Howrah and the Forest Research Institute, Dehradun. After making comparison with them it was concluded that the fossil is close to Firmiana colorata $(=S$. colorata $)$ (Herbarium sheet no. FRI 123878) and S. urens (Herbarium sheet no. FRI 1856) (figures 3b, 4b, d). The fossil also shows some resemblance with Acer pictum Thunb. of the family Sapindaceae but more acute angle of divergence of secondary veins and presence of both random reticulate and percurrent
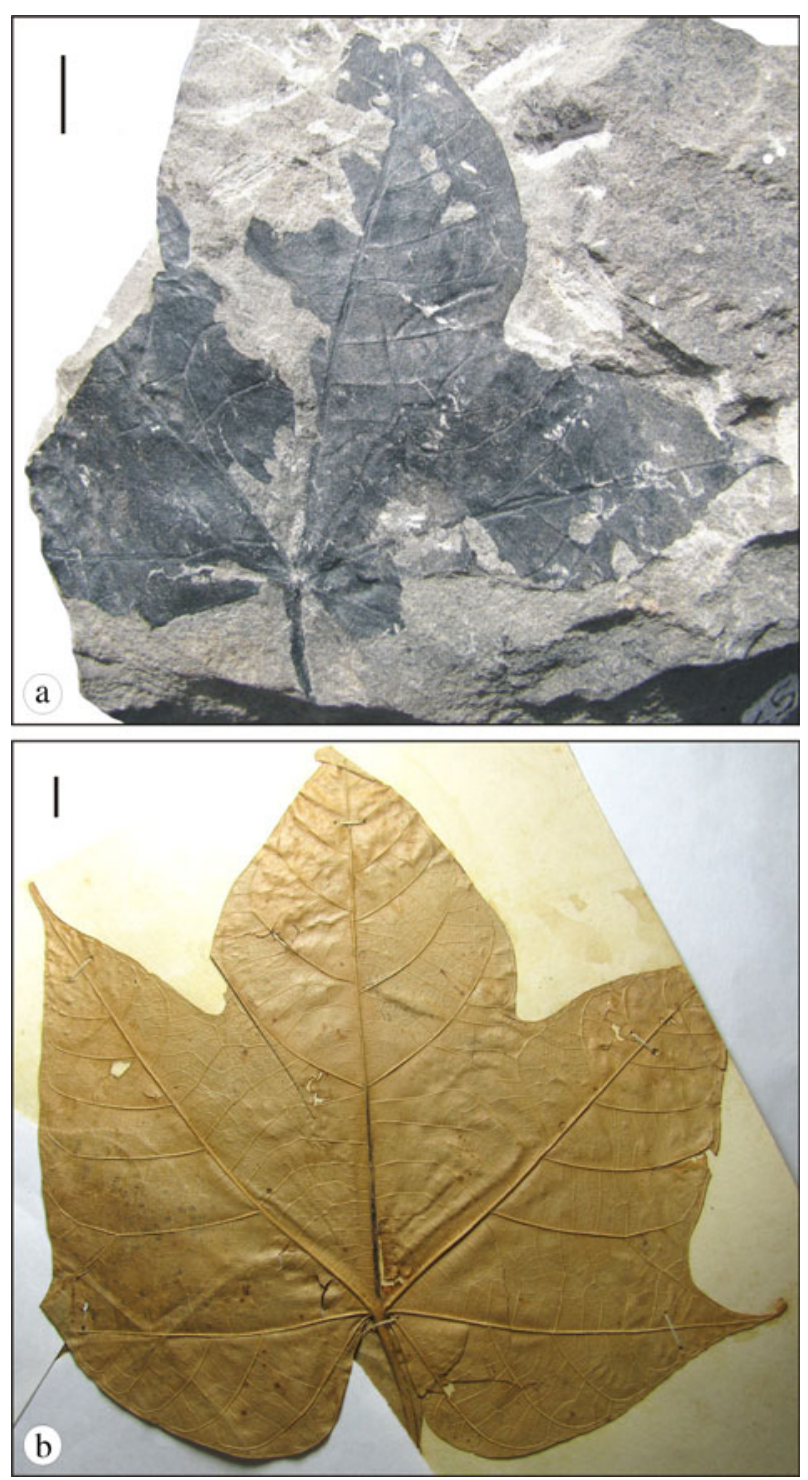

Figure 3. (a) Fossil leaf of Firmiana oligocenica sp. nov. showing shape, size and venation pattern; and (b) modern leaf of Sterculia urens showing similar shape, size and venation pattern as in the fossil leaf (scale bar $=1 \mathrm{~cm})$. 

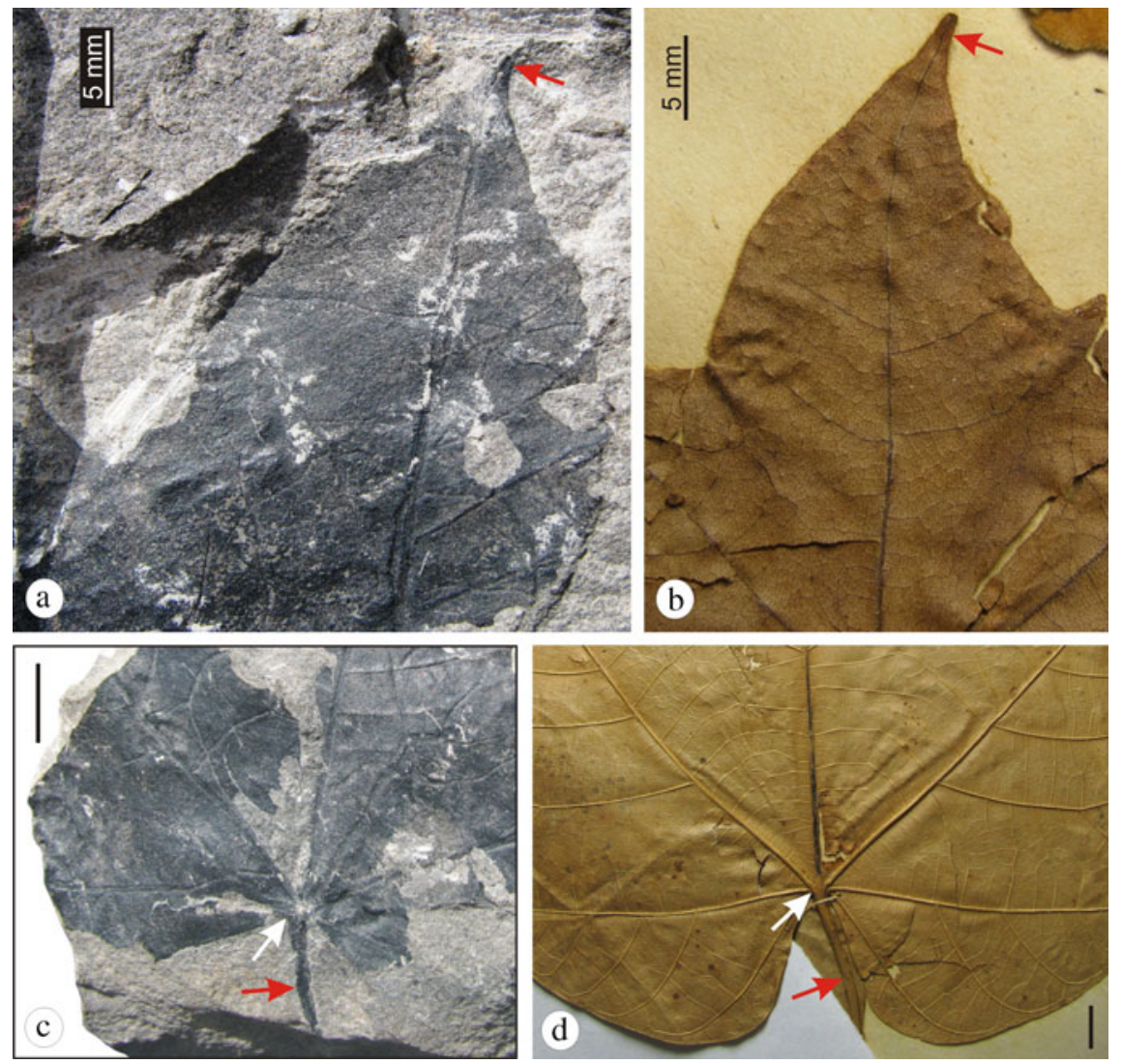

Figure 4. (a) Apical portion of a lobe of the fossil leaf (F. oligocenica sp. nov.) showing attenuate apex (red arrow); (b) apical portion of a lobe of the modern leaf (S. urens) showing similar apex (red arrow); (c) basal portion of the fossil leaf showing actinodromous venation and cordate base (white arrow) and petiole (red arrow); and (d) basal portion of the modern leaf showing similar actinodromous venation and cordate base (white arrow) and petiole (red arrow) (scale bar $=$ $1 \mathrm{~cm}$, unless otherwise given).

tertiaries in the latter differentiate it from the fossil leaf. In Sterculia acerifolia, S. bidwilli and S. diversifolia lamina is deeply lobed, while in $S$. pallens and $S$. trichosiphon lamina lobing is small as compared to that of the fossil. Pterygota alata Thwaites (syn. Sterculia alata Roxb.), Sterculia coccinea, S. foetida, S. guttata, S. rupestris and $S$. versicolor are different from the fossil in having unlobed lamina. In S. platanifolia, the angle of divergence of secondary veins is more acute in comparison to that of the fossil.

As far as the authors are aware, there is no fossil record of Firmiana but fossil leaf and fruit of Sterculia are known from various Cenozoic horizons. A fossil fruit of Sterculia, viz., S. palaeovillosa was described by Mehrotra (2000a) from the same horizon from where the present fossil was collected. Bande and Srivastava (1990) have described a fragmentary leaf of Sterculia villosa from the late Cenozoic sediments of Mahuadanr, Palamu District, Bihar. Sterculia kathgodamense described by Prasad (1994) from the Lower Siwalik sediments of Kathgodam, S. tertiara described by Shashi et al. (2006) from the Lower Siwalik sediments of Champawat District, Uttaranchal, S. mioensifolia as well as S. premontana described by Prasad and Pandey (2008) from the late Miocene sediments of Surai Khola, Nepal and Sterculia versicolor described by Singh and Prasad (2010) from late Tertiary sediments of Latehar District, Jharkhand have unlobed lamina in contrast to the lobed lamina of the present fossil. A fossil leaf described by Carvalho et al. (2011) as Malvaciphyllum macondicus from the Palaeocene sediments of South America shows some similarity with the present fossil but its dentate margin makes the difference. As the present fossil shows close resemblance with Firmiana and Sterculia, the authors have preferred the name Firmiana as per alphabetical order. As it is different from all the known records, it is being described as Firmiana oligocenica Srivastava and Mehrotra, sp. nov., the specific epithet is after its age. The present fossil becomes the first record of Firmiana.

The genus Firmiana consists of about 12 species of trees found in Old World tropics (Mabberley 
1997). Firmiana colorata (= Sterculia colorata) is found in Pegu, Bangladesh, western peninsula and Sri Lanka. Sterculia consists of 150 species distributed in tropical areas of the world (Mabberley 1997). S. urens Roxb. is found in northwest India, Assam, Bihar, eastern and western peninsula and Sri Lanka (Hooker 1872-1897).

Specific diagnosis: Leaf palmately lobed, three lobes seen; apex attenuate; base cordate; margin entire; texture chartaceous; attachment with petiole normal; venation pinnate, actinodromous; secondary veins eight pairs visible, $0.4-0.7 \mathrm{~cm}$ apart, predominantly alternate, angle of divergence moderate-wide acute, smoothly curved; intersecondary veins not seen; tertiary veins percurrent and recurved, angle of origin RR.

Holotype: Specimen no. BSIP 40061.

Horizon: Tikak Parbat Formation.

Locality: Tirap Colliery, Tinsukia District, Assam $\left(27^{\circ} 17^{\prime} 20^{\prime \prime} \mathrm{N}, 95^{\circ} 46^{\prime} 15^{\prime \prime} \mathrm{E}\right)$.

Age: Late Oligocene (Chattian 28.1-23 Ma).

Number of specimens studied: One.

Genus: Pterygota Endl.

Species: P. palaeoalata Srivastava and Mehrotra, sp. nov. (figures $5 \mathrm{a}-\mathrm{c}, 6 \mathrm{~b}, \mathrm{c}$ )

Description: Leaf more or less complete, symmetrical, mesophyll, narrow elliptic; preserved lamina length $25.3 \mathrm{~cm}$ and maximum width $10.1 \mathrm{~cm}$ (near the middle part); apex attenuate; base slightly broken, symmetrical, cordate; margin entire; texture chartaceous; venation pinnate, actinodromous, basal, perfect; mid-vein curved in upper half of lamina, moderate in thickness, three pairs of lateral primaries arising from the base of mid-vein, the outer lateral vein on each side thin and arising at right angle $\left(92^{\circ}\right)$, two inner lateral primaries on each side stout, arising at an angle of $38^{\circ}-80^{\circ}$, curving upward and running up to nearly half of the length of lamina; secondary veins arising from primaries fine, angle of divergence moderatewide acute $\left(62^{\circ}-76^{\circ}\right), 2.1-3.1 \mathrm{~cm}$ apart, predominantly alternate, moderate in thickness, smoothly curved and joining superadjacent secondary veins through the tertiary veins; intersecondary veins absent; tertiary veins percurrent, simple, recurved, oblique in relation to mid-vein, angle of origin ARAA, alternate-opposite; marginal ultimate venation looped; quaternary veins orthogonal; areoles predominantly quadrangular, imperfect, random; veinlets branched; leaf mines frequently present all over the surface of lamina.
Affinities: The characteristic features of the fossil leaf, viz., narrow elliptic shape, attenuate apex, cordate base, actinodromous venation, percurrent tertiary veins and absence of intersecondary veins suggest its close affinity with that of Pterygota (syn. Sterculia) of the family Malvaceae s.l. (formerly Sterculiaceae). A number of herbarium sheets were examined in the Central National Herbarium, Howrah and the Forest Research Institute, Dehradun. After making comparison with a large number of taxa of the family Malvaceae such as Brachychiton acerifolium Macarthur and Moore, Firmiana colorata Roxb. (= Sterculia colorata), Firmiana simplex (L.) W. Wight, Kleinhovia hospita L., Pterygota alata Thwaites $(=S$. alata Roxb.), Sterculia acerifolia Hemsl., S. bidwilli Hk. ex Benth., S. coccinea Roxb., S. diversifolia G. Don, S. guttata Roxb., S. pallens Wall. ex Hochr., S. platanifolia L. f., S. rubiginosa Zoll. ex Miq., S. rupestris Benth., S. trichosiphon Benth., S. urens Roxb., S. versicolor Wall. and S. villosa Roxb., it may be inferred that the fossil shows similarity with that of Pterygota alata (Herbarium sheet no. FRI 3330) (figures 5d, 6a, d, e). In Firmiana simplex, Sterculia acerifolia, S. bidwilli, $S$. platanifolia, S. trichosiphon, S. urens and S. villosa, the leaves are lobed in contrast to the unlobed lamina of the present fossil. Brachychiton acerifolium, Sterculia coccinea, S. diversifolia, S. rubiginosa and $S$. versicolor have eucamptodromous venation which differentiates them from the fossil. Though Sterculia guttata and S. rupestris have actinodromous venation, occurrence of only one pair of lateral primaries makes them different from the present fossil. Similarly, Firmiana colorata (= Sterculia colorata) has only two pairs of lateral primaries unlike the present fossil. Sterculia pallens has both lobed and unlobed lamina and actinodromous venation but the apex is acute-obtuse in contrast to the present fossil where it is attenuate. In Kleinhovia hospita, the venation is actinodromous but the distance between two secondary veins is comparatively less which makes it different from the fossil.

As far as the fossil leaf record of Pterygota is concerned, it is known from various Cenozoic horizons. Bande and Srivastava (1990) have described a fossil leaf of Pterygota alata from the late Cenozoic beds of Mahuadanr, Palamu District, Bihar. It shows similarity with the present fossil in a combination of characters. Pterygota cordata (cf. P. alata) described by Awasthi and Mehrotra (1995) has two pairs of lateral primaries with secondary veins only. Under such conditions, it is difficult to compare it with the present fossil. A very fragmentary specimen cf. Pterygota alata is also described by Mathur et al. (1996) but due to its fragmentary nature its identification becomes doubtful. 

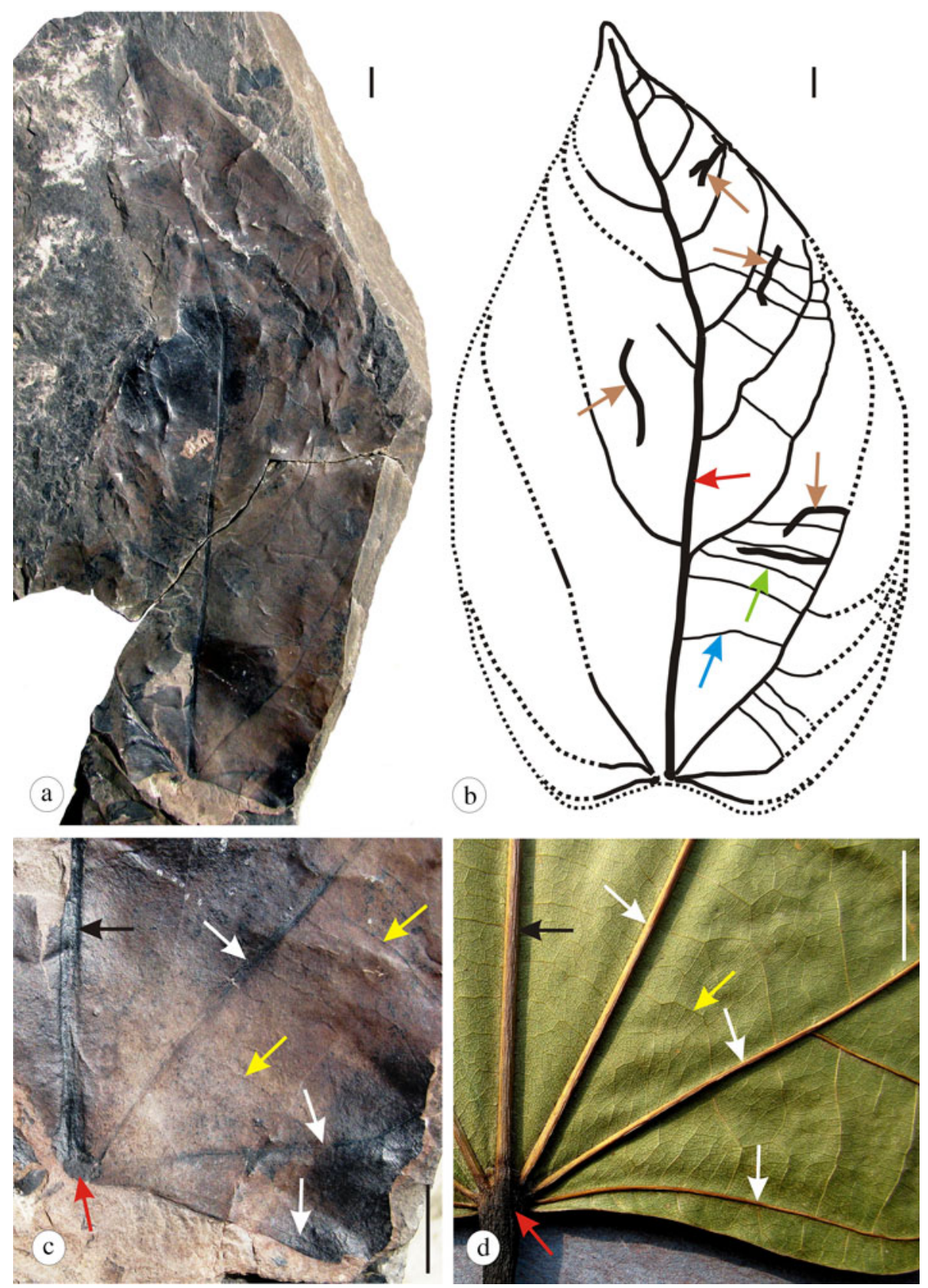

Figure 5. (a) A fossil leaf of Pterygota palaeoalata sp. nov. showing shape, size and and venation pattern; (b) text diagram of the fossil leaf showing insect mines (brown arrows), primary vein (red arrow), recurved and percurrent tertiary veins (blue and green arrow); (c) basal portion of the fossil leaf showing actinodromous venation, i.e., middle primary (black arrow) and several lateral primary veins (white arrows) emerging from the single locus (red arrow) and percurrent tertiary veins (yellow arrows); and (d) basal portion of the modern leaf showing actinodromous venation, i.e., middle primary (black arrow) and several lateral primary veins (white arrows) emerging from the single locus (red arrow) and percurrent tertiary vein (yellow arrow) (scale bar $=1 \mathrm{~cm})$.

Fossil leaf described as Malvaciphyllum macondicus (Carvalho et al. 2011) from the Palaeocene sediments of South America shows some similarity with the present fossil but its dentate margin makes the difference. Therefore, a new species, Pterygota palaeoalata Srivastava and Mehrotra, sp. nov., has been created, the specific epithet is after the modern species - Pterygota alata.
The genus Pterygota consists of about 20 species distributed throughout the tropics of Old World (Willis 1973). P. alata is a tall evergreen tree found in the evergreen forest of northeast India (particularly Assam) and Western Ghats but reaches its best development in Chittagong, Myanmar and Andamans (Ramesh Rao 1958). 

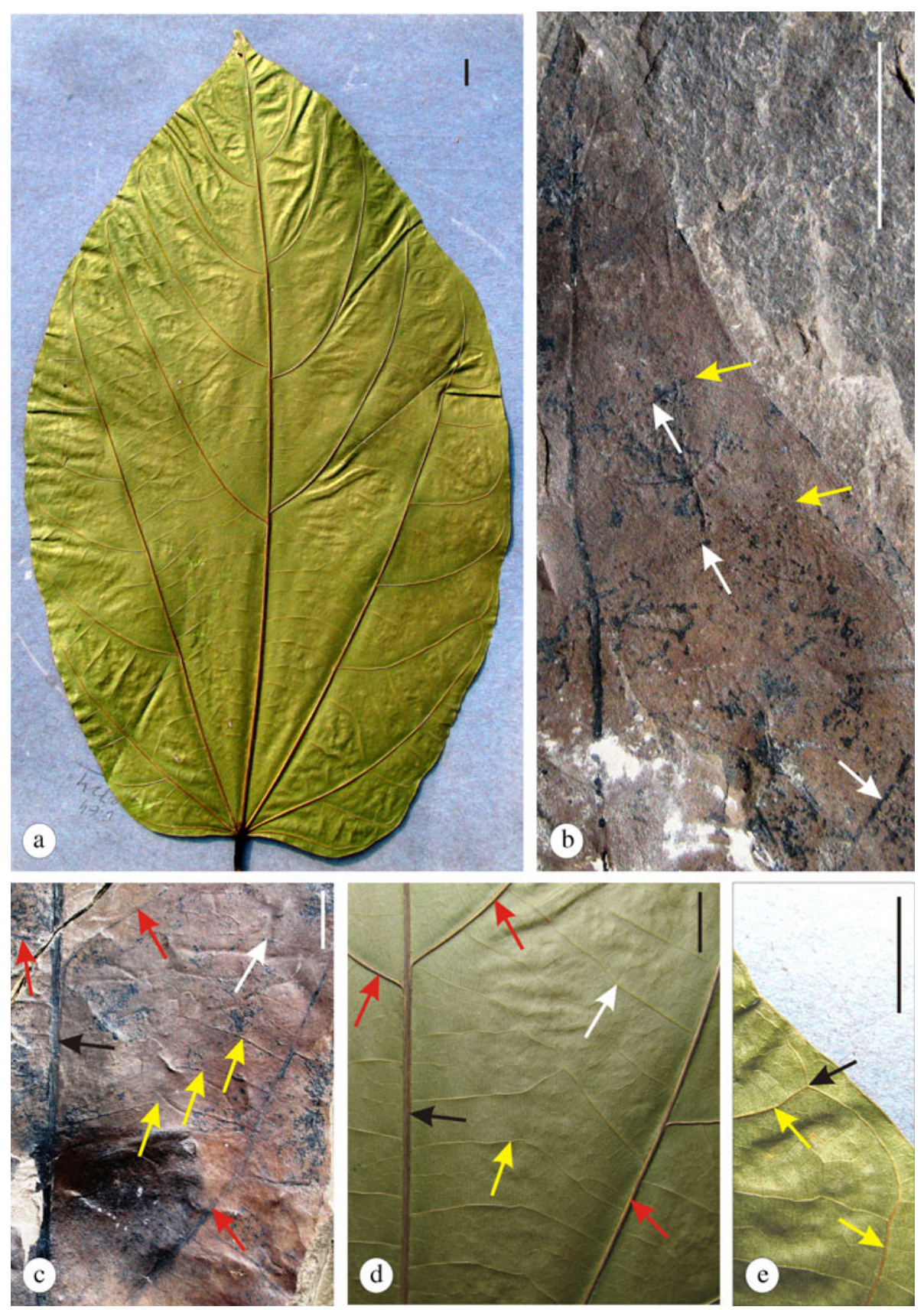

Figure 6. (a) A modern leaf of Pterygota alata showing similar shape, size and venation pattern as in the fossil (figure 5a, b); (b) apical portion of the fossil leaf ( $P$. palaeoalata sp. nov.) where two secondary veins (white arrows) join each other (yellow arrows); (c) middle portion of the fossil leaf showing primary vein (black arrow), secondary veins (red arrows), recurved and percurrent tertiary veins (yellow and white arrows); (d) middle portion of the modern leaf showing similar primary vein (black arrow), secondary veins (red arrows), recurved and percurrent tertiary veins (yellow and white arrows) and (e) marginal portion of the apical part of the modern leaf where two secondary veins (yellow arrows) join each other (black arrow) (scale bar $=1 \mathrm{~cm})$.

Specific diagnosis: Leaf symmetrical, narrow elliptic; apex attenuate; base symmetrical, cordate; margin entire; texture chartaceous; venation pinnate, actinodromous, basal, perfect; three pairs of lateral primaries arising from the base of mid-vein, the outer lateral vein on each side thin and arising at right angle, two inner lateral primaries on each side stout, arising at acute angle, curving upward and running up to nearly half of the length of lamina; secondary veins arising from primaries fine, angle of divergence moderatewide acute, predominantly alternate, smoothly curved and joining superadjacent secondary veins through the tertiary veins; intersecondary veins absent; tertiary veins percurrent, simple, recurved, oblique in relation to mid-vein, angle of origin AR-AA, alternate-opposite; marginal ultimate venation looped; quaternary veins orthogonal; 


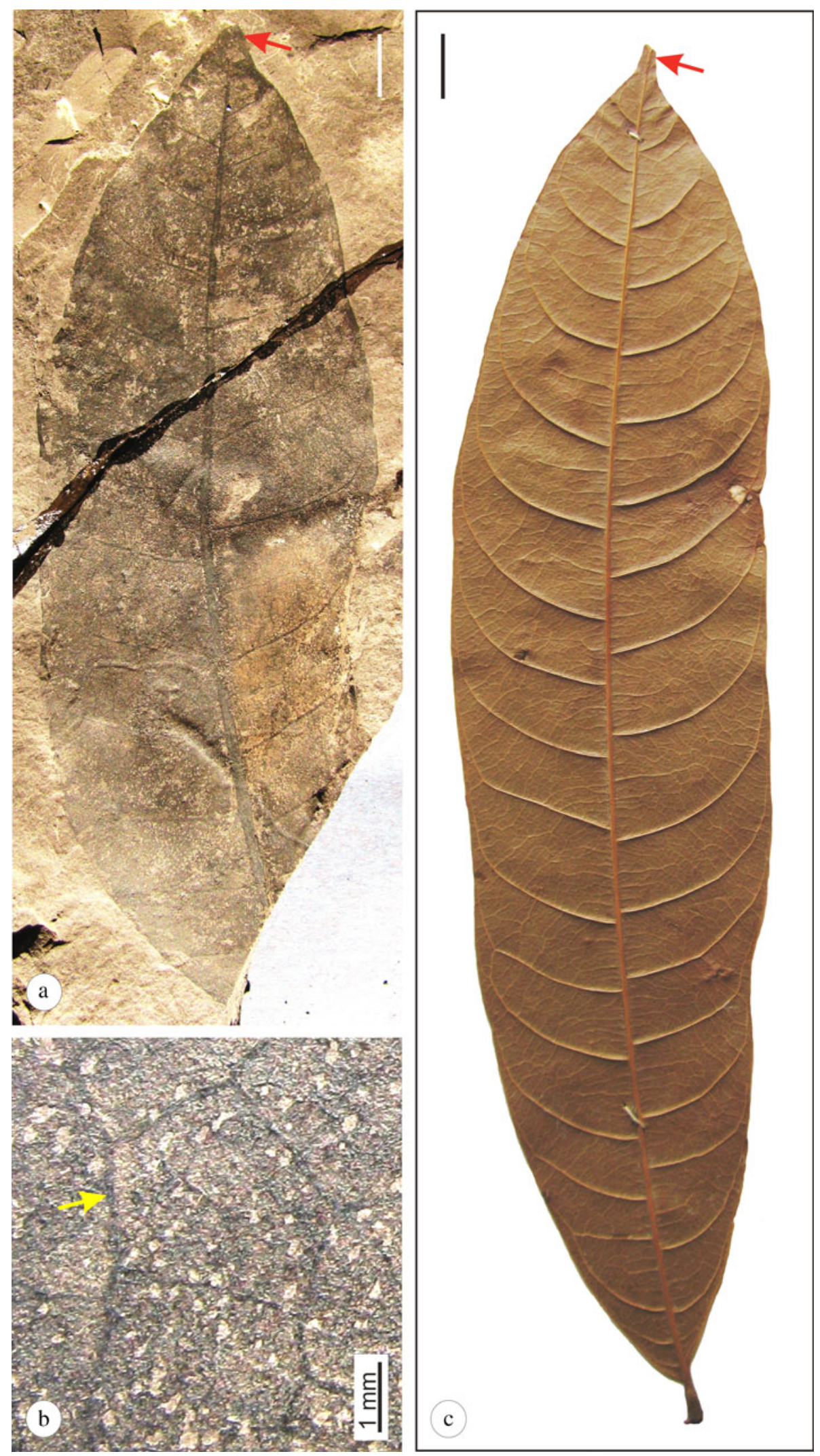

Figure 7. (a) Fossil leaf of Paranephelium makumensis sp. nov. showing shape, size, venation pattern and attenuate apex (red arrow); (b) enlarged portion of the fossil leaf showing pentagonal areole (yellow arrow); and (c) a modern leaf of Paranephelium xestophyllum showing similar shape, size, venation pattern and attenuate apex (red arrow) (scale bar $=$ $1 \mathrm{~cm}$, unless otherwise mentioned). 
areoles predominantly quadrangular, imperfect, random; veinlets branched.

\section{Holotype: Specimen no. BSIP 40062A.}

Horizon: Tikak Parbat Formation.

Locality: Tirap Colliery, Tinsukia District, Assam $\left(27^{\circ} 17^{\prime} 20^{\prime \prime} \mathrm{N}, 95^{\circ} 46^{\prime} 15^{\prime \prime} \mathrm{E}\right)$.

Age: Late Oligocene (Chattian 28.1-23 Ma).

Number of specimens studied: One.

Order: Sapindales Juss. ex Bercht. and Presl

Family: Sapindaceae Juss.

Genus: Paranephelium Miq.

Species: P. makumensis Srivastava and Mehrotra, sp. nov. (figures 7a, 8a, c)

Description: Leaf symmetrical, mesophyll, narrow elliptic; preserved lamina length $15.6 \mathrm{~cm}$, maximum width $5.5 \mathrm{~cm}$ (near the middle); apex seemingly attenuate; base broken; margin entire, wavy; texture chartaceous; venation pinnate, eucamptodromous; primary vein stout in thickness, slightly curved; secondary veins 14 pairs visible, 0.7-1.9 $\mathrm{cm}$ apart, predominantly alternate, angle of divergence moderate-wide acute to right $\left(55^{\circ}-\right.$ $93^{\circ}$ ), abruptly curved just near the margin, moderate in thickness; intersecondary veins present, simple, 1-2; tertiary veins percurrent, simple, forked, angle of origin OA-AR; areoles well developed and quadrangular to pentagonal in shape.

Affinities: The characteristic features of the fossil leaf, viz., symmetrical lamina, narrow elliptic shape, attenuate apex, entire margin, eucamptodromous venation, moderate-wide acute to right angle of divergence of secondary veins, simple intersecondaries and percurrent tertiary veins suggest its close similarity with the modern leaf of
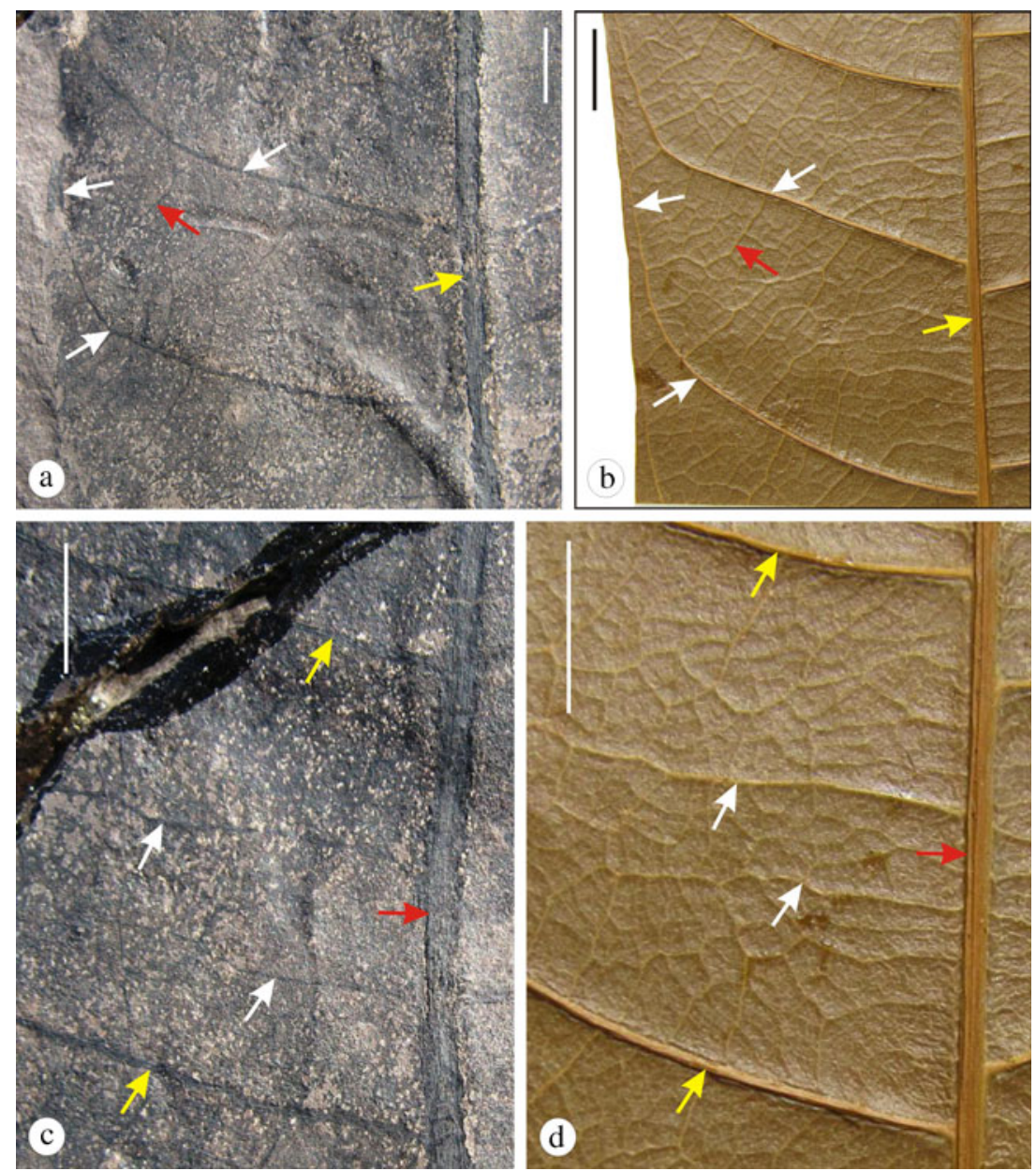

Figure 8. (a) A middle portion of the fossil leaf ( $P$. makumensis sp. nov.) showing secondary veins with eucamptodromous venation (white arrows), primary and tertiary veins (yellow and red arrows); (b) a middle portion of the modern leaf ( $P$. xestophyllum) showing similar secondary veins with eucamptodromous venation (white arrows), primary and tertiary veins (yellow and red arrows); (c) enlarged portion of the fossil leaf showing intersecondary (white arrows), secondary (yellow arrows) and primary veins (red arrow); and (d) enlarged portion of the modern leaf showing similar intersecondary (white arrows), secondary (yellow arrows) and primary veins (red arrow) (scale bar $=0.5 \mathrm{~cm}$ ). 
Paranephelium Miq., particularly P. xestophyllum Miq. (=P. hystrix Smith) (Herbarium sheet no. FRI 42582) (figures 7c, 8b, d) of the family Sapindaceae. A large number of herbarium sheets were examined in the Central National Herbarium, Howrah and the Forest Research Institute, Dehradun. The fossil also shows similarities with Xerospermum noronhianum Bl., Sapindus detergens Roxb., S. mukorossi Gaertn., S. thwaitesii Hiern, Lepisanthes burmanica Kurz of the Sapindaceae and Mangifera indica L. and Bouea oppositifolia Meisn. of the Anacardiaceae. Both Xerospermum noronhianum and Sapindus detergens are very much similar to the fossil leaf but the angle of divergence of secondary veins is more acute in them than in the fossil. In Sapindus mukorossi, secondary veins are smoothly curved near the margin in contrast to the present fossil where they are abruptly curved. In $S$. thwaitesii, the angle of divergence of secondary veins is wide acute to right and tertiary veins are random reticulate which make the major difference from the fossil. Lepisanthes burmanica is also very much similar but the distance between the two secondary veins is lesser in it than in the fossil. Mangifera indica shows similar features as found in the fossil but the distance between the two secondary veins is comparatively less and tertiary veins are percurrent, recurved-retroflexed and orthogonal reticulate unlike the present fossil. Bouea oppositifolia also shows some similarities with the fossil leaf but the angle of divergence of secondary veins is wide acute to right and margin is not wavy in it; this marks the difference.

As far as the fossil record of Paranephelium is concerned, its only fossil, Paranephelium seriaensis (Prasad and Dwivedi 2008), is known from the middle Miocene sediments of western Nepal. It has acute apex, distance between two secondary veins is $0.7-1.2 \mathrm{~cm}$, angle of divergence of secondary veins is moderate acute and shows absence of intersecondary veins; all these features are in contrast to the present fossil leaf where apex is attenuate, secondaries are comparatively far apart with moderately acute to right angle of divergence and intersecondary veins are present. Therefore, a new species, Paranephelium makumensis Srivastava and Mehrotra, sp. nov., has been created, the specific epithet is after the Makum Coalfield.

Paranephelium is a small genus consisting of four species distributed in southeast Asia and western Malaysia. It is small-to-medium sized tree of the lower canopy or higher understorey of the primary rain forest, mixed deciduous forest or dry evergreen forest, especially in the moist part near streams, sometimes in secondary forest, rarely in scrub; typical of lowlands and the lower hillside (Davids 1984). Paranephelium xestophyllum, a closely comparable species of the fossil, is a small evergreen tree found mainly in the primary rain forest, also in mixed deciduous, dry evergreen, partly secondary or disturbed forest, rarely in (seasonal) swamp. It is distributed in China, Myanmar, Thailand, Indochinese peninsula, Malayan peninsula, Sumatra, Kalimantan and Philippines (Davids 1984).

Specific diagnosis: Leaf symmetrical, narrow elliptic; apex attenuate; margin entire; texture chartaceous; venation pinnate, eucamptodromous; primary vein stout in thickness; secondary veins $0.7-1.9 \mathrm{~cm}$ apart, predominantly alternate, angle of divergence moderate-wide acute to right, abruptly curved near the margin; intersecondary veins present, simple, 1-2; tertiary veins percurrent, simple, forked; areoles quadrangular to pentagonal in shape.

Holotype: Specimen no. BSIP 40063.

Horizon: Tikak Parbat Formation.

Locality: Tirap Colliery, Tinsukia District, Assam $\left(27^{\circ} 17^{\prime} 20^{\prime \prime} \mathrm{N}, 95^{\circ} 46^{\prime} 15^{\prime \prime} \mathrm{E}\right)$.

Age: Late Oligocene (Chattian 28.1-23 Ma).

Number of specimens studied: One.

Genus: Sapindus Plum.

Species: S. palaeoemarginatus Srivastava and Mehrotra, sp. nov. (figures 9a, c, e)

Description: Leaf complete, symmetrical, mesophyll, suborbiculate elliptic; preserved lamina length $6 \mathrm{~cm}$; maximum width $5 \mathrm{~cm}$ near the middle; apex emarginate; base symmetrical, obtuse to round; margin entire; texture coriaceous; venation pinnate eucamptodromous; primary vein stout in thickness, nearly straight; secondary veins 5 pairs visible, $0.5-0.6 \mathrm{~cm}$ apart, predominantly alternate, angle of divergence wide acute $\left(68^{\circ}-78^{\circ}\right)$, uniform, moderately thick, uniformly curved; intersecondary veins present, simple; tertiary veins random reticulate, other features not visible.

Affinities: The characteristic features of the fossil leaf, viz., suborbiculate elliptic shape, emarginate apex, obtuse to round base, eucamptodromous venation, simple intersecondaries and random reticulate tertiary veins suggest its close affinity with that of Sapindus of the family Sapindaceae. A large number of herbarium sheets of Sapindus species, namely $S$. attenuatus Wall., $S$. detergens Roxb., S. emarginatus Vahl, S. laurifolius Vahl, S. mukorossi Gaertn. and S. thwaitesii Hiern were examined in the Central National Herbarium, Howrah and the Forest Research Institute, Dehradun. After making comparison with 
them, it is suggested that the present fossil is close to $S$. emarginatus (figure $9 \mathrm{~b}, \mathrm{~d}, \mathrm{f}$ ). The other species such as $S$. attenuatus, $S$. detergens and $S$. mukorossi have attenuate apex and acute base and are thus different from the present fossil. In S. laurifolius and $S$. thwaitesii shape of leaf is elliptic and base is acute unlike the present fossil. Ceriops roxburghiana Arn. of the family Rhizophoraceae is also very similar to the present fossil leaf but it has brochidodromous venation which differentiates it from the present fossil.

As far as fossil record of Sapindus leaf is concerned, it is known from both India and abroad. From India, only two types of leaves are known, viz., leaf type $\mathrm{D}$ and leaf type E comparable to $S$. bilinicus and $S$. falcifolius respectively (Deshmukh and Sharma 1978). In both these leaves, the apex is acute and acuminate respectively and the base is acute; these features differentiate them from the present fossil. Sapindus graecus and $S$. falcifolius are known from the late Oligocene sediments of Bulgaria (Bozukov et al. 2008). In the former the leaf is narrow elliptic with attenuate apex and acute base which make the difference from the present fossil, while in the latter the leaf is elliptic in shape. S. falcifolius is also known from the middle Miocene of Morilor Valley of Romania (Paraschiv 2004). Its leaf is asymmetrical, oblonglanceolate in shape with cuneate base and acuminate apex; all these features differentiate it from the present fossil. As the present fossil is distinct from all known species, it is being described under a new species, Sapindus palaeoemarginatus Srivastava and Mehrotra, sp. nov., the specific name is after the modern species - Sapindus emarginatus.
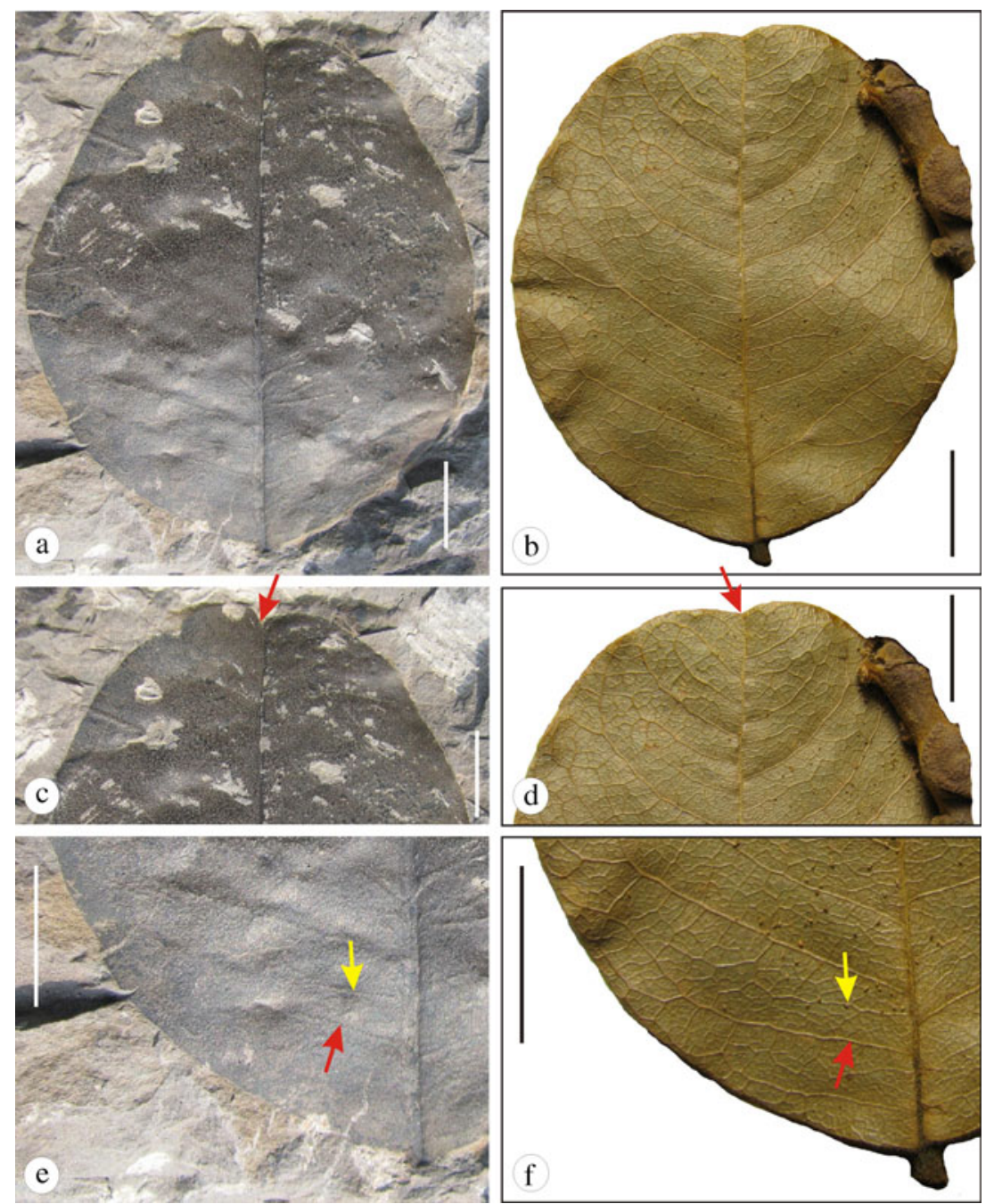

Figure 9. (a) Fossil leaf of Sapindus palaeoemarginatus sp. nov. showing shape, size and venation pattern; (b) modern leaf of Sapindus emarginatus showing similar shape, size and venation pattern as in the fossil; (c) apical portion of the fossil leaf showing emarginate apex (red arrow); (d) apical portion of the modern leaf showing similar emarginate apex as in the fossil (red arrow); (e) a portion of fossil leaf showing secondary and intersecondary veins (red and yellow arrows); and (f) a portion of the modern leaf showing similar secondary and intersecondary veins as in the fossil (red and yellow arrows) (scale bar $=1 \mathrm{~cm}$ ). 
The genus Sapindus is a tree or shrub consisting of 15 species found in tropical and warm climate; about 7 species are found in India. S. emarginatus Vahl is a common tree, found mostly in West Bengal and peninsular India in deciduous and evergreen forests (Santapau and Henry 1973).

Specific diagnosis: Leaf symmetrical, shape suborbiculate elliptic; apex emarginate; base symmetrical, obtuse to round; margin entire; texture coriaceous; venation eucamptodromous; angle of divergence of secondary veins wide acute; intersecondary veins present, simple; tertiary veins random reticulate.

Holotype: Specimen no. BSIP 40064A.

Horizon: Tikak Parbat Formation.

Locality: Tirap Colliery, Tinsukia District, Assam $\left(27^{\circ} 17^{\prime} 20^{\prime \prime} \mathrm{N}, 95^{\circ} 46^{\prime} 15^{\prime \prime} \mathrm{E}\right)$.

Age: Oligocene (Chattian 28.1-23 Ma).

Number of specimens studied: One.

\section{Discussion and conclusion}

The family Malvaceae consists of $\sim 250$ genera with $\sim 4500$ species distributed in tropical to temperate regions of the world (Carvalho et al. 2011). Recent studies have merged Sterculiaceae, Tiliaceae and Bombacaceae into the expanded Malvaceae (Bayer et al. 1999; Bayer and Kubitzki 2003) and nine subfamilies have been recognized based on various morphological and anatomical synapomorphies as well as molecular data (Judd and Manchester 1997; Alverson et al. 1998, 1999; Bayer et al. 1999) in contrast to 10 families concept (Baum et al. 1998; Cheek 2006; Heywood et al. 2007). In the present paper we have followed Malvaceae s.l. for describing the fossil malvalean leaves as it is used by a majority of modern taxonomists. The fossil record of the family dates back to late Campanianearly Maastrichtian of Mexico (Estrada-Ruiz et al. 2010); late Cretaceous sediments of Texas (Wheeler and Lehman 2000); middle-late Palaeocene sediments of Columbia (Carvalho et al. 2011); early Miocene of Czech Republic (Kvaček 2004). In India, the oldest fossil record of the family is known from the Deccan Intertrappean sediments of central India (Chitaley and Sheikh 1973); also recorded from the late Paleocene, late Oligocene and Neogene sediments of northeast India (Srivastava and Mehrotra 2010b), Neogene sediments of western, southern and northern India (Guleria 1992; Prasad 2008).

The family Sapindaceae (Sapindales) contains 142 genera and 1900 species (Buerki et al. 2009) which are predominantly pantropical in distribution. Some taxa such as Acer L., Aesculus L., Atalaya Bl., Diplopeltis Endl. and Dodonaea Jacq. are distributed in temperate regions with main centre of diversity in south Asian region. The family is also economically important for fruits like Dimocarpus longan Lour., Litchi chinensis Sonn., Paullinia cupana Kunth; wood like Aesculus L. (Buerki et al. 2009). It consists of four sub-families such as Xanthoceroideae, Hippocastanoideae, Dodonaeoideae and Sapindoideae (Stevens 2001) which diverged between 116 and $98 \mathrm{Ma}$, and spread mainly from Laurasia while southeast Asia persisting as a significant area in the evolution of the family (Buerki et al. 2011). The fossil record of the family is known from the Oligocene and Miocene sediments of Africa; late Oligocene-early Miocene of southeast Bulgaria (Bozukov et al. 2008); Miocene sediments of Romania (Paraschiv 2004); late Miocene sediments of Poland (Walther and Zastawniak 2005); and Eocene of Oregon (Manchester 1994; Wheeler et al. 2006). From India, the oldest fossil record of the family is from the Deccan Intertrappean sediments of Maharashtra (Kar et al. 2004) and central India (Dayal 1965; Chitaley and Shallom 1969; Mehrotra 1987). It is also known from the late Palaeocene, late Oligocene and Neogene sediments of northeast India (Srivastava and Mehrotra 2010b); Siwalik sediments of northern India (Prasad 2008) and Neogene sediments of Gujarat and Pondicherry (Guleria 1992).

Phytogeographically, the family Malvaceae s.l. is important for India and southeast Asia indicating the migration of taxa in deep time (Bande and Prakash 1986). The family is represented in India by the genus Sterculia from the MaastrichtianPalaeogene sediments while it made its first appearance in the Neogene sediments of Myanmar as Sterculinium foetidense (Prakash 1973; Guleria 1983). Likewise, another genus Pterospermum was present in the Palaeogene sediments of Borneo as Phyllites (Pterospermum) gracilis (Geyler 1875), while it made its first appearance in the Neogene sediments of India (Awasthi et al. 1980; Antal and Awasthi 1994; Antal and Prasad 1996; Roy and Mukhopadhyay 2005; Srivastava et al. 2012c). Similar is the case for the genus Grewia which was recorded from the Deccan Intertrappeans (MaastrichtianDanian) (Prakash and Dayal 1965; Paradkar and Dixit 1984; Bande and Srivastava 1995; Khare et al. 2000; Srivastava and Guleria 2000) and late Palaeocene sediments (Mehrotra 2000b) of India. This genus was later recorded from the Neogene sediments of South Vietnam and Myanmar (Serra 1981; Gottwald 1994). The above records suggest that a free floral migration occurred from India to southeast Asia and vice-versa after the complete suturing of the Indian and Asian plates during the 
Low latitude leaf assemblage from the late Oligocene sediments of Assam

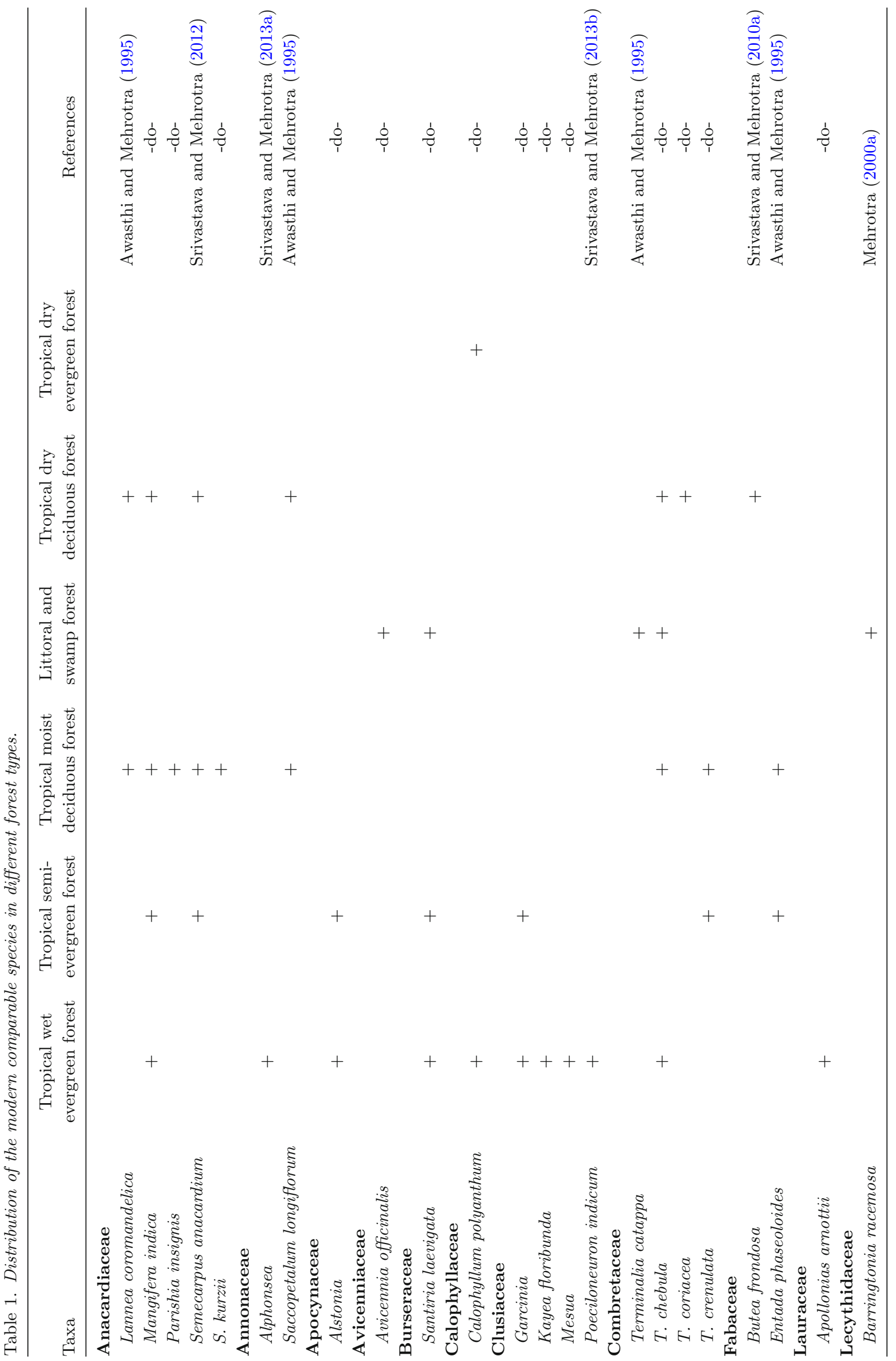




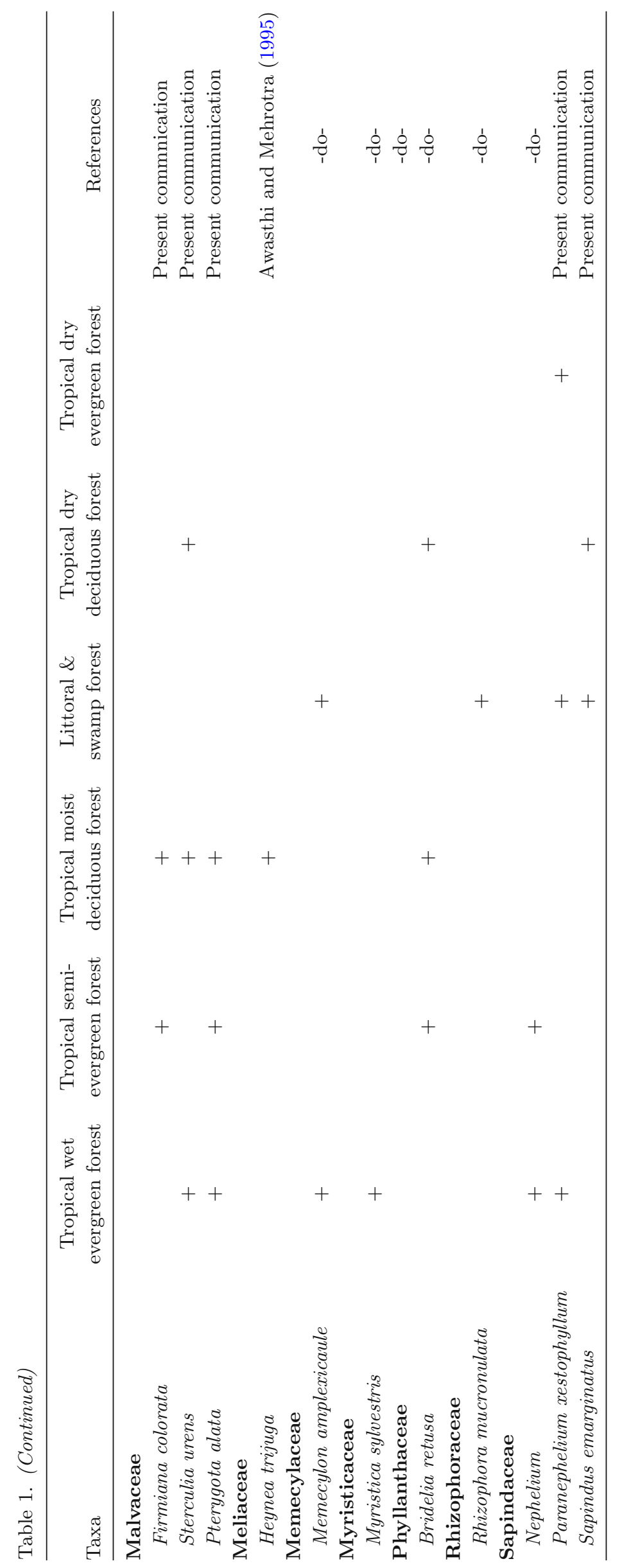




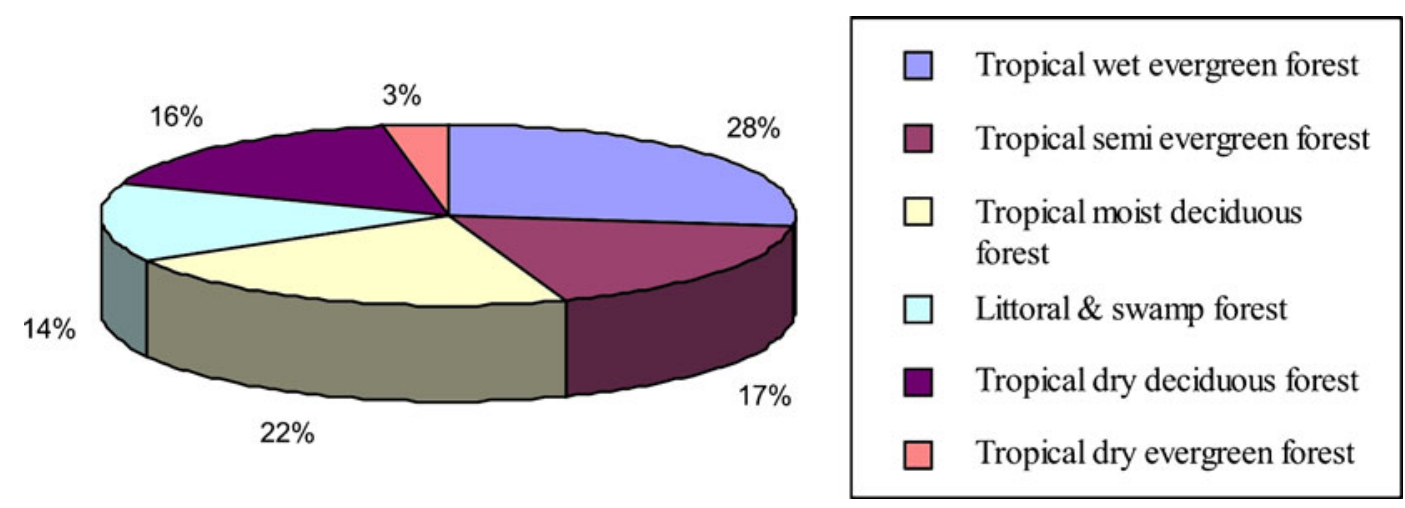

Figure 10. Different forest types in the assemblage of Makum Coalfield.

beginning of Neogene (Srivastava and Mehrotra 2010b). There are several other families and genera which indicate the floral migration in between the two landmasses in the geologic past and this was discussed in great detail by Bande and Prakash (1986) and Tiwari et al. (2012).

For the reconstruction of palaeoclimate, qualitative and quantitative study was made on the flora of Makum Coalfield, Assam. Qualitative study is based on the floristic assemblages containing the families listed in table 1. Among them, the families such as Annonaceae, Burseraceae, Clusiaceae, Combretaceae, Lecythidaceae, Myristicaceae and Rhizophoraceae are typical pantropical (van Steenis 1962) and their presence in the Makum Coalfield palaeoflora provides evidence that the CMMT (cold month mean temperature) was not less than $18^{\circ} \mathrm{C}$ (Srivastava et al. 2012b). Similarly, the dominance of Fabaceae (Srivastava and Mehrotra 2010a) whose abundance and richness covary with temperature (Punyasena et al. 2008), also indicates a warm climate. The occurrence of Avicenniaceae and Rhizophoraceae is significant in terms of the depositional environment. These families are highly indicative of deltaic, mangrove or lacustrine deposition of sediments in the Makum Coalfield. The presence of palms like Nypa (Mehrotra et al. 2003) provides further evidence of a coastal plain environment where both temperature and humidity remained high throughout the year (Tomlinson 1990). The overall floristic assemblage indicates a dominance of moist conditions (figure 10). For quantitative study, CLAMP (Climate Leaf Analysis Multivariate Program) analysis was made on 80 different morphotypes of fossil leaves, including the presently described assemblage from the Tirap mine indicating MAT (mean annual temperature) $28.3^{\circ} \pm 3.7^{\circ} \mathrm{C}$; CMMT $23^{\circ} \pm 5.5^{\circ} \mathrm{C}$ and a WMMT (warm month mean temperature) of $33.6^{\circ} \pm 5.2^{\circ} \mathrm{C}$ and a monsoonal climate during the late Oligocene (Srivastava et al. 2012b).

\section{Acknowledgements}

The authors are thankful to the authorities of the Coal India Limited (Northeastern Region), Margherita for permission to collect plant fossils from the Makum Coalfield. Thanks are also due to the Directors, Botanical Survey of India, Kolkata and the Forest Research Institute, Dehradun for permitting us to consult the herbarium. The authors are also thankful to Dr N C Mehrotra, Director, Birbal Sahni Institute of Palaeobotany, Lucknow for providing necessary facilities and permission to carry out the present work.

\section{References}

Ahmed M 1996 Petrology of Oligocene coal, Makum coalfield, Assam, northeast India; Int. J. Coal Geol. 30 319-325.

Alverson W S et al. 1998 Circumscription of the Malvales and relationships to other Rosidae: Evidence from $r b c L$ sequence data; Am. J. Bot. 85 876-887.

Alverson W S, Whitlock B A, Nyffeler R, Bayer C and Baum D A 1999 Phylogeny of core Malvales: Evidence from $n d h F$ sequence data; Am. J. Bot. 86 1474-1486.

Antal J S and Awasthi N 1994 Fossil flora from the Himalayan foot-hills of Darjeeling District, West Bengal and its palaeoecological and phytogeographical significance; Palaeobotanist 42(1) 14-60.

Antal J S and Prasad M 1996 Some more leaf impressions from the Himalayan foot-hills of Darjeeling District, West Bengal, India; Palaeobotanist 43(2) 1-9.

Awasthi N and Mehrotra R C 1995 Oligocene flora from Makum Coalfield, Assam, India; Palaeobotanist 44 157-188.

Awasthi N, Guleria J S and Lakhanpal R N 1980 Fossil dicotyledonous woods from the Pliocene beds of Mothala, district Kutch, western India; Palaeobotanist 26(3) $199-205$.

Awasthi N, Mehrotra R C and Lakhanpal R N 1992 Occurrence of Podocarpus and Mesua in the Oligocene sediments of Makum Coalfield, Assam, India; Geophytology 22 193-198. 
Bande M B and Prakash U 1986 The Tertiary flora of southeast Asia with remarks on its palaeoenvironment and phytogeography of the Indo-Malayan region; Rev. Palaeobot. Palynol. 49 203-233.

Bande M B and Srivastava G P 1990 Late Cenozoic plantimpressions from Mahuadanr Valley, Palamu District, Bihar; Palaeobotanist 37(3) 331-366.

Bande M B and Srivastava R 1995 Grewia-type of fossil woods from the Deccan Interterappean beds of India; Geophytology 24(2) 131-136.

Baum D A, Alverson W S and Nyffeler R 1998 A durian by any other name: Taxonomy and nomenclature of core Malvales; Harvard Pap. Bot. 3(2) 315-330.

Bayer C and Kubitzki K 2003 Malvaceae; In: The families and genera of vascular plants $V$. Flowering plants Dicotyledons, Malvales, Capparales and non-betalain Caryophyllales (eds) Kubitzki K and Bayer C (Berlin: Springer-Verlag), pp. 225-310.

Bayer C et al. 1999 Support for an expanded family concept of Malvaceae within a recircumscribed order Malvales: A combined analysis of plastid $a t p B$ and $r b c L$ DNA sequence; Bot. J. Linn. Soc. 129 267-303.

Bozukov V, Palamarev E and Petkova A 2008 The fossil macroflora of the Vulche Pole Molasse formation (SE Bulgaria); Phytol. Balcan. 14(2) 173-184.

Buerki S et al. 2009 Plastid and nuclear DNA markers reveal intricate relationships at subfamilial and tribal levels in the soapberry family (Sapindaceae); Mol. Phylogenet. Evol. 51 238-258.

Buerki S et al. 2011 An evaluation of new parsimony-based versus parametric inference methods in biogeography: A case study using the globally distributed plant family Sapindaceae; J. Biogeogr. 38 531-550.

Carvalho M R, Herrera F A, Jaramillo C A, Wing S L and Callejas R 2011 Paleocene Malvaceae from northern South America and their biogeographical implications; Am. J. Bot. 98(8) 1337-1355.

Cheek M 2006 The validation of two new family names in Malvales: Durionaceae and Brownlowiaceae; Kew Bull. 61443.

Chitaley S D and Shallom L J 1969 Sapindoxylon chhindwarensis sp. nov., a new fossil dicot wood from the Deccan Intertrappean beds of Madhya Pradesh, India; J. Indian Bot. Soc. 48(1-2) 38-43.

Chitaley S D and Sheikh M T 1973 A ten locular petrified fruit from the Deccan Intertrappean Series of India; Palaeobotanist 20(3) 297-299.

Davids M 1984 A taxonomic revision of Paranephelium (Sapindaceae); Blumea 29 425-441.

Dayal R 1965 Sapindoxylon schleicheroides sp. nov., a fossil dicotyledonous wood from the Deccan Intertrappean beds of Madhya Pradesh; Palaeobotanist 13(2) 163-167.

Deshmukh G P and Sharma B D 1978 Fossil plants from the Eocene of Barmer, Rajasthan (India); Trans. Isat. Ueds. 3(2) 88-90.

Dilcher D L 1974 Approaches to the identification of angiosperm leaf remains; Bot. Rev. 40 1-157.

Ellis B, Daly D C, Hickey L J, Johnson K R, Mitchell J D, Wilf P and Wing S L 2009 Manual of Leaf Architecture (Ithaka: Cornell University Press).

Estrada-Ruiz Emilio, Martínez-Cabrera Hugo I and Cevallos-Ferriz Sergio R S 2010 Upper Cretaceous woods from the Olmos Formation (Late Campanian-Early Maastrichtian), Coahuila, Mexico; Am. J. Bot. 97(7) 1179-1194.

Ganju J I, Khare B M and Chaturvedi J S 1986 Geology and hydrocarbon prospects of Naga Hills south of $27^{\circ}$ latitude; Bull. Oil and Natural Gas Commission 23 $129-145$.
Geyler T T 1875 Über fossile Pflanzen von Borneo; Palaeontographica Suppl. 3 1(1) 61-84.

Gottwald H 1994 Tertiäre hölzer aus dem Chindwin-Bassin im nordwestlichen Myanmar (Birma); Documentae naturae 86 1-90.

Guleria J S 1983 Some fossil woods from Tertiary of Kachchh, western India; Palaeobotanist 31(3) 109-128.

Guleria J S 1992 Neogene vegetation of peninsular India; Palaeobotanist 40 285-311.

Heywood V H, Brummitt R K, Culham A and Seberg O 2007 Flowering plant families of the world (Kew: Royal Botanic Gardens).

Hickey L J 1973 Classification of the architecture of dicotyledonous leaves; Am. J. Bot. 60 17-33.

Hooker J D 1872-1897 The Flora of British India (Kent: L. Reeve and Co.) 1-7 1872-1897.

Judd W S and Manchester S R 1997 Circumscription of Malvaceae (Malvales) as determined by a preliminary cladistic analysis of morphological, anatomical, palynological and chemical characters; Brittonia 49 384-405.

Kar R K, Sharma N and Verma V K 2004 Plant pathogen Protocolletotrichum from a Deccan Intertrappean beds (Maastrichtian) of India; Cret. Res. 25 945-950.

Khare E G, Prasad M and Awasthi N 2000 Contributions to the Deccan Intertrappean flora of Nawargaon, Wardha District, Maharashtra, India; Palaeobotanist 49(3) 443-460.

Kumar M, Srivastava G, Spicer R A, Spicer T E V, Mehrotra R C and Mehrotra N C 2012 Sedimentology, Palynostratigraphy and Palynofacies of the Late Oligocene Makum Coalfield, Assam, India: A window on lowland tropical vegetation during the most recent episode of significant global warmth; Palaeogeogr. Palaeoclimatol. Palaeoecol. 342-343 143-162.

Kvaček Z 2004 Early Miocene records of Craigia (Malvaceae s.l.) in the Most Basin, North Bohemia - Whole plant approach; J. Czech Geol. Soc. 49 161-171.

Mabberley D J 1997 The plant book, a portable dictionary of the vascular plants (Cambridge: Cambridge University Press).

Manchester S R 1994 Fruits and seeds of the Middle Eocene Nut Beds flora, Clarno Formation, Oregon; Palaeontogr. Am. 58 1-201.

Mathur A K, Mishra V P and Mehra S 1996 Systematic study of plant fossils from Dagshai, Kasauli and Dharamsala formations of Himachal Pradesh; Geol. Surv. India, Palaeontologia Indica N.S. 50 1-121.

Mehrotra R C 1987 A new fossil dicot wood from the Deccan intertrappean beds of Mandla district, Madhya Pradesh; Geophytology 17(2) 204-208.

Mehrotra R C 2000a Two new fossil fruits from Oligocene sediments of Makum Coalfield, Assam, India; Curr. Sci. 79(10) 1482-1483.

Mehrotra R C 2000b Study of plant megafossils from the Tura Formation of the Nangwalbibra, Garo Hills, Meghalaya, India; Palaeobotanist 49 225-237.

Mehrotra R C, Dilcher D L and Lott T A 2009 Notes on elements of the Oligocene flora from the Makum Coalfield, Assam, India; Palaeobotanist 58 1-9.

Mehrotra R C, Tiwari R P and Mazumder B I 2003 Nypa megafossils from the tertiary sediments of northeast India; Geobios 36 83-92.

Mishra H K and Ghosh R K 1996 Geology, petrology and utilization of some tertiary coals of the northeastern region of India; Int. J. Coal Geol. 30 65-100.

Misra B K 1992 Tertiary coals of Makum Coalfield, Assam, India: Petrography, genesis and sedimentation; Palaeobotanist 39(3) 309-326. 
Molnar P and Stock J M 2010 Slowing of India's convergence with Eurasia since $20 \mathrm{Ma}$ and its implications for Tibetan mantle dynamics; Tectonics 28 TC3001.

Paradkar S A and Dixit V P 1984 Grewia mohgaoensis - a new petrified dicotyledonous fruit from the Deccan Intertrappean Beds of Mohgaon Kalan, Madhya Pradesh, India; In: Proc. 5th Indian Geophytological Conference, Lucknow, 1983 (eds) Tiwari R S et al. (Lucknow: Special Publication of the Palaeobotanical Society), pp. $155-162$.

Paraschiv V 2004 The fossil flora of the Morilor valley, southwestern Dacian basin, Romania; Acta Palaeontologica Romaniae 4 315-330.

Pascoe E H 1964 A Manual of the Geology of India and Burma (Calcutta: Geol. Surv. India).

Prakash U 1973 Fossil woods from the Tertiary of Burma; Palaeobotanist 20(1) 48-70.

Prakash U and Dayal R 1965 Fossil woods of Grewia from the Deccan Intertrappean Series, India; Palaeobotanist 13(1) 17-24.

Prasad M 1994 Plant megafossils from the Siwalik sediments of Koilabas, central Himalaya, Nepal and their impact on palaeoenvironment; Palaeobotanist 42(2) 126-156.

Prasad M 2008 Angiospermous fossil leaves from the Siwalik foreland basins and their palaeoclimatic implications; Palaeobotanist 57 177-215.

Prasad M and Dwivedi H D 2008 Studies on plant megafossils from the sub-Himalayan zone (Siwalik) of western Nepal and their palaeoclimatic implications; J. Palaeontol. Soc. India 53(1) 51-64.

Prasad M and Pandey S M 2008 Plant diversity and climate during Siwalik (Miocene-Pliocene) in the Himalayan foot hills of western Nepal; Palaeontographica B 278 13-70.

Punyasena S W, Eshel G and McElwain J C 2008 The influence of climate on the spatial patterning of neotropical plant families; J. Biogeogr. 35 117-130.

Qinghai Z, Willems H, Ding Lin, Gräfe Kai-Uwe and Appel E 2012 Initial India-Asia continental collision and foreland basin evolution in the Tethyan Himalaya of Tibet: Evidence from stratigraphy and paleontology; $J$. Geol. 120 175-189.

Ramesh Rao K 1958 Family Sterculiaceae; In: Indian woods 1 (eds) Chowdhury K A and Ghosh S (Delhi: The Manager of Publications), pp. 194-223.

Roy S K and Mukhopadhyay S 2005 Fossil wood resembling Pterospermum Schreb. (Sterculiaceae) and Tectona Linn. (Verbenaceae) from the Tertiary of West Bengal, India; In: Gleanings in botanical research - current scenario, Ramanujam Commemoration Volume (ed.) Bir Bahadur (Nagpur: Dattsons), pp. 221-231.

Santapau H and Henry A N 1973 A Dictionary of the Flowering Plants in India (New Delhi: Publication and Information Directorate).

Serra C 1981 Les structures ligneuses Néogénes du Plateau de Linch (Sud Vietnam); Palaeontographica B 117(5-6) 136-161.

Shashi, Pandey S M and Tripathi P P 2006 Fossil leaf impressions from Siwalik sediments of Himalayan foot hills of Uttaranchal, India and their significance; Palaeobotanist 55 77-87.
Singh S K and Prasad M 2010 Late Tertiary flora of Mahuadanr Valley, Latehar District, Jharkhand, India; Geophytology 38(1-2) 45-55.

Srivastava G and Mehrotra R C 2010a New legume fruits from the Oligocene sediments of Assam; J. Geol. Soc. India 75 820-828.

Srivastava G and Mehrotra R C 2010b Tertiary flora of northeast India vis-à-vis movement of the Indian plate; Geol. Soc. India Memoir 75 123-130.

Srivastava G and Mehrotra R C 2012 The oldest fossil of Semecarpus L.f. from the Makum Coalfield, Assam, India and comments on its origin; Curr. Sci. 102(3) 398-400.

Srivastava G and Mehrotra R C 2013a First fossil record of Alphonsea Hk. f. \& T. (Annonaceae) from the late Oligocene sediments of Assam, India and comments on its phytogeography; PLOS ONE 8(1) e53177.

Srivastava G and Mehrotra R C 2013b Endemism due to climate change: Evidence from Poeciloneuron Bedd. (Clusiaceae) leaf fossil from Assam, India; J. Earth Syst. Sci. 122(2) 283-288.

Srivastava G, Mehrotra R C and Bauer H 2012a Palm leaves from the Late Oligocene sediments of Makum Coalfield, Assam; J. Earth Syst. Sci. 121(3) 747-754.

Srivastava G, Spicer R A, Spicer T E V, Yang J, Kumar M, Mehrotra R C and Mehrotra N C 2012b Megaflora and Palaeoclimate of a Late Oligocene Tropical Delta, Makum Coalfield, Assam: Evidence for the Early Development of the South Asia Monsoon; Palaeogeogr. Palaeoclimatol. Palaeoecol. 342-343 130-142.

Srivastava R, Saxena R K and Srivastava G 2012c Pterospermumocarpon, a new malvalean fruit from the Sindhudurg Formation (Miocene) of Maharashtra, India, and its phytogeographical significance; J. Earth Syst. Sci. 121(1) 183-193.

Srivastava R and Guleria J S 2000 Grewinium, a substitute name for Grewioxylon Shallom non Schuster; Palaeobotanist 49 531-532.

Stevens P F 2001 Angiosperm phylogeny website, http:// www.mobot.org/MOBOT/research/APweb/.

Tiwari R P, Mehrotra R C, Srivastava G and Shukla A 2012 The vegetation and climate of a Neogene petrified wood forest of Mizoram, India; J. Asian Earth Sci. 61 143-165.

Tomlinson P B 1990 The structural biology of palms (Oxford: Clarendon Press).

van Steenis C G G J 1962 The land-bridge theory in botany; Blumea 11(1) 235-372.

Walther H and Zastawniak E 2005 Sapindaceae (Aceroideae) from the late Miocene flora of Soánica near Wrocław-a revision of Göppert's original materials and a study of more recent collections; Acta Palaeobot. 45(1) 85-106.

Wheeler E A and Lehman T M 2000 Late Cretaceous woody dicots from the Aguja and Javelina Formations, Big Bend National Park, Texas, USA; IAWA 21(1) 83-120.

Wheeler E A, Manchester S R and Wiemann M 2006 Eocene woods of central Oregon; PaleoBios 26(3) 1-6.

Willis J C 1973 A Dictionary of the Flowering Plants and Ferns (Cambridge: Cambridge University Press).

Zachos J, Pagani M, Sloan L, Thomas E and Billups K 2001 Trends, rythms, and aberrations in global climate $65 \mathrm{Ma}$ to present; Science 292 686-693. 